\title{
STUDI KOMPARASI PENERAPAN MANAJEMEN RISIKO PRODUK PEMBIAYAAN DI LEMBAGA KEUANGAN MIKRO SYARIAH
}

\section{COMPARATIVE STUDY OF RISK MANAGEMENT IMPLEMENTATION OF FINANCING PRODUCTS IN MICRO SHARIA FINANCIAL INSTITUTIONS}

\author{
R.T. Yulianti1,a; A. Bustami1; N. Atiqoh¹; R. Anjellah'1 \\ 1Program Studi Ekonomi Islam Fakultas Ilmu Agama Islam Universitas Islam Indonesia, \\ Jl. Kaliurang Km. 14,5 Yogyakarta 55584 \\ aKorespondensi: Rahmani Timorita Yulianti, Tel. 08122728772, E-mail: \\ rahmani_ty@yahoo.com,rahmanitimorita@uii.ac.id
}

\begin{abstract}
Risk is a consequence that can not be eliminated from business activities, but can be minimized by applying risk management. The purpose of this study is to describe the comparison of risk management implementation between murabahah and mudharabah financing products in Sharia Micro Finance Institution. This research is a qualitative research with interview and documentation research instrument. The results show that the application of risk management to murabahah and mudaraba financing has similarities in the process. The implementation of risk management in both financing schemes is initiated from risk identification, risk evaluation and measurement, and ends with risk management. In practice, the implementation of risk management in these two schemes is different. In murabahah financing, risk identification is performed as the first step in risk management. Risk measurement is done as a benchmark to understand the significance of the loss that would be caused by a risk. Risk evaluation is performed to control or supervise the extent of the risk handling that has been done so as not to risk back. Risk management is done by way of assistance, reimbursement, extension of payback period, return of principal, warning, confiscation, customer search, and write off or collect off. While in mudharabah financing, risk identification is done at the beginning of mudharabah financing application, and when conducting a survey before the realization of mudharabah financing. Risk measurement is done by using integrated information management system through integrated micro banking system (IBS) software. Risk evaluation is done through data in the bookkeeping system through IBS, and surveys to mudharabah finance members. The risk management that has been done is done by giving explanation, giving back time, pay the principal, and confiscation of the guarantee.
\end{abstract}

Keywords: Murabahah, Mudharabah, Risk Management, Financing, LKMS

\section{ABSTRAK}

Risiko adalah suatu akibat yang tidak dapat dihilangkan dari kegiatan bisnis, tetapi dapat diminimalisir dengan menerapkan manajemen risiko. Tujuan penelitian ini adalah mendiskripsikan perbandingan penerapan manajemen risiko antara produk pembiayaan murabahah dan mudharabah di Lembaga Keuangan Mikro Syariah. Penelitian ini adalah penelitian kualitatif dengan istrumen penelitian wawancara dan dokumentasi. Hasil penelitian menunjukan bahwa penerapan manajemen risiko pada 
pembiayaan murabahah dan mudharabah memiliki kesamaan dalam prosesnya. Penerapan manajemen risiko di kedua skim pembiayaan ini sama-sama dimulai dari proses identifikasi risiko, evaluasi dan pengukuran risiko, dan diakhiri dengan pengelolaan risiko. Dalam pelaksanaannya, penerapan manajemen risiko di kedua skim ini memiliki perbedaan. Dalam pembiayaan murabahah, identifikasi risiko dilakukan sebagai langkah pertama dalam manajemen risiko. Pengukuran risiko dilakukan sebagai dasar tolak ukur untuk memahami signifikansi akibat kerugian yang akan ditimbulkan oleh suatu risiko. Evaluasi risiko dilakukan untuk mengontrol atau mengawasi sejauh mana penanganan risiko yang telah dilakukan agar tidak timbul risiko kembali. Pengelolaan risiko dilakukan dengan cara pendampingan, pemberian modal kembali, perpanjangan jangka waktu pengembalian, pengembalian pokok, pemberian peringatan, sita jaminan, pencarian nasabah, dan hapus buku atau hapus tagih. Sedangkan dalam pembiayaan mudharabah, identifikasi risiko dilakukan pada saat awal permohonan pembiayaan mudharabah, dan saat melakukan survei sebelum realisasi pembiayaan mudharabah. Pengukuran risiko dilakukan dengan menggunakan sistem manajemen informasi yang terintegrasi melalui software integrated micro banking system (IBS). Evaluasi risiko dilakukan melalui data dalam sistem pembukuan melalui IBS, dan survei kepada anggota pembiayaan mudharabah. Pengelolaan risiko yang sudah terjadi dilakukan dengan cara memberikan penjelasan, pemberian kelonggaran waktu pengembalian, membayar pokok, dan penyitaan jaminan.

Kata Kunci: Murabahah, Mudharabah, Manajemen Risiko, Pembiayaan, LKMS

Yulianti, Bustami, Atiqoh, dan Anjellah. 2018. Studi Komparasi Penerapan Manajemen Risiko Produk Pembiayaan Di Lembaga Keuangan Mikro Syariah. Jurnal Syarikah 4 (1): 59-71.

\section{PENDAHULUAN}

Seiring dengan perkembangan teknologi, dunia bisnis lembaga keuangan mengalami perubahan yang cukup signifikan. Perubahan-perubahan yang terjadi secara tidak langsung telah merubah karakteristik-karakteristik risiko yang dihadapi oleh lembaga keuangan. Dua dekade yang lalu, lembaga keuangan pada dasarnya hanya dihadapkan pada risiko kredit dan pasar. Namun saat ini, lembaga keuangan terbuka terhadap berbagai bentuk risiko yang baru. (Iqbal dan Mirakhor 2008)

Klasifikasi lembaga keuangan di Indonesia meliputi Lembaga Keuangan Bank dan Lembaga Keuangan Non Bank. Lembaga Keuangan Mikro Syariah seperti Baitul Maal wat Tamwil (BMT) adalah salah satu bentuk Lembaga Keuangan Non
Bank. Secara kelembagaan, BMT merupakan Lembaga Keuangan Mikro Syariah yang berbadan hukum koperasi yang dapat beroperasi berdasarkan Undang-undang No. 17 tahun 2012 yaitu sebagai koperasi produsen, konsumen, jasa dan simpan pinjam. (Yusuf 2013)

Dalam kegiatan operasionalnya, BMT sampai saat ini belum dijamin oleh lembaga penjamin simpanan (LPS). Sehingga BMT memiliki risiko yang cukup besar, terutama dalam hal penyaluran pembiayaan. Dalam menyalurkan pembiayaannya, secara umum BMT menggunakan akad murabahah dengan basis margin keuntungan dan akad mudharabah dengan basis bagi hasil. Produk-produk yang disalurkan dengan menggunakan kedua akad tersebut samasama rentan terhadap risiko-risiko yang terjadi. Baik risiko yang berdampak 
kepada nasabah, maupun kepada lembaga keuangan itu sendiri. Oleh karena itu perlu ada penerapan manajemen risiko yang tepat terhadap produk-produk tersebut.

Laporan posisi keuangan pembukaan koperasi LKM Syariah menunjukkan bahwa pada desember 2016 penggunaan skim pembiayaan murabahah di LKMS mencapai 24,26 persen, sedangkan pada skim pembiayaan mudharabah adalah sebesar 5,39 persen. Hal ini menunjukkan bahwa penggunaan skim pembiayaan murabahah lebih tinggi dibanding dengan skim pembiayaan mudharabah (OJK 2016). Adanya kesenjangan dalam penggunaan skim pembiayaan antara murabahah dan mudharabah ini menarik untuk diteliti lebih lanjut. Terutama terkait dengan penerapan manajemen risiko di kedua akad tersebut.

Manajemen risiko memiliki peranan penting dalam keberlangsungan suatu usaha, karena manajemen risiko memiliki prosedur dan metode yang dapat digunakan untuk meminimalisir risiko. Prosedur dan metode tersebut meliputi kegiatan mengidentifikasi, mengukur, memantau, serta mengendalikan risiko.

Adapun dalam penelitian ini, penulis akan mengeksplorasi lebih lanjut terkait perbandingan penerapan manajemen risiko pada produk pembiayaan murabahah di BTM Surya Umbulharjo Yogyakarta dan produk pembiayaan mudharabah di BMT Usaha Artha Sejahtera Pamotan, Rembang, Jawa Tengah. Tujuan dari penelitian ini adalah untuk mendiskripsikan perbandingan penerapan manajemen risiko antara produk pembiayaan murabahah dan mudharabah di Lembaga Keuangan Mikro Syariah.

\section{MATERI DAN METODE}

\section{Baitul Maal Wa Tamwil (BMT)}

Secara konseptual Baitul Maal wan Tamwil (BMT) adalah suatu lembaga yang terdiri dari penggabungan dua lembaga, yaitu baitu maal dan baitul tamwil. Baitul maal adalah lembaga yang kegiatan usahanya mengumpulkan dan menyalurkan dana non profit, seperti zakat, infaq dan sedekah. Sedangkan baitul tamwil adalah lembaga yang kegiatan usahanya mengumpulkan dan menyalurkan dana komersial. Usahausaha tersebut menjadi bagian dari BMT sebagi lembaga pendukung kegiatan ekonomi masyarakat kecil dengan berlandaskan prinsip syariah. (Sudarsono 2008)

BMT menawarkan produk pembiayaan berupa penyediaan uang dan tagihan berdasarkan pesetujuan atau kesepakatan pinjam-meminjam di antara BMT dengan yang lain yang mewajibkan pihak peminjam untuk melunasi uangnya beserta bagi hasil setelah jangka waktu tertentu. Produk pembiayaan tersebut antara lain adalah Pembiayaan alMurabaha (MBA), Pembiayaan al-Bai'i Bitsaman Ajil (BBA), Pembiayaann alMudharabah (MDA), dan Pembiayaan alMusyarakah (MSA). (Sudarsono 2008)

\section{Pembiayaan Murabahah}

Menurut para fuqaha, murabahah adalah penjualan barang seharga biaya/harga pokok (cost) barang tersebut ditambah mark-up atau margin keuntungan yang disepakati. Keunikan akad murabahah yaitu, pembeli harus diberitahu selisih harga jual dan harga beli yang merupakan keuntungan pada pembiayaan tersebut. (Wiroso 2005).

Singkatnya, murabahah adalah akad jual beli barang dengan menyatakan harga perolehan dan keuntungan (margin) yang disepakati oleh penjual dan pembeli (Karim 2007). Dalam Lembaga Keuangan Syariah, pembiayaan murabahah dapat digunakan untuk 
pembiayaan modal kerja, pembiayaan investasi, dan pembiayaan konsumtif (Widodo 2014).

\section{Pembiayaan Mudharabah}

Secara teknis Mudharabah adalah akad kerjasama usaha antara dua pihak di mana pihak pertama (shohibul maal) menyediakan seluruh (100\%) modal, sedangkan pihak lainnya menjadi pengelola. Bagi hasil dalam pembiayaan mudharabah disepakati dalam sebuah kontrak yang mengatur pembagian keuntungan sesuai kesepakatan. Adapun jika mengalami kerugian, akan dibebankan kepada pemilik modal, kecuali disebabkan oleh kelalaian pengelola. Seandainya kerugian itu diakibatkan karena kecurangan atau kelalaian si pengelola harus bertanggung jawab atas kerugian tersebut. (Antonio M. S., 2001)

Menurut fatwa DSN MUI No.07/DSN-MUI/IV/2000 bahwa pada prinsipnya, dalam pembiayaan Mudharabah tidak ada jaminan, tetapi untuk meminimalisir penyimpangan yang mungkin dilakukan mudharib, maka LKS dapat meminta jaminan dari mudharib. Dan jaminan ini hanya dapat dicairkan apabila mudharib terbukti melakukan pelanggaran terhadap hal-hal yang telah disepakati di awal akad. (DSN MUI 2000)

Adapun tujuan dikenaknnya jaminan pada akad Mudharabah adalah untuk menghidndari moral hazard mudharib (Asiyah 2015). Serta untuk memberikan efek psikologis, agar mudharib lebih berhati-hati. Hal ini sejalan dengan ketentuan AAOIFI yang menyebutkan bahwa penyedia dana/pemilik modal diizinkan untuk memperoleh jaminan dari mudharib yang memadai dan dapat dilaksanakan. Namun hal ini dibatasi oleh syarat bahwa sohibul mal tidak akan melakukan likuidasi, kecuali jika terjadi kelalaian yang dilakukan oleh mudharib. (Widodo 2014)

Adapun bentuk penerapan pembiayaan Mudharabah di LKS terbagi terbagi menjadi tiga, yaitu pembiayaan modal kerja seperti pembiayaan modal bagi perusahaan yang bergerak dalam industri, perdagangan, dan jasa; pembiayaan investasi seperti pembiayaan untuk pengadaan barang-barang modal, aktiva tetap dan sebagainya; dan pembiayaan investasi khusus, yaitu LKS bertindak sebagai pihak yang mempertemukan kepentingan pemilik dana dengan pengusaha yang memerlukan dana. (Rivai dan Veithzal 2010)

\section{Risiko Pembiayaan Murabahah}

Pembiayaan murabahah merupakan pembiayaan yang dicirikan dengan adanya penyerahan barang diawal akad dan pembayaran kemudian, baik dalam bentuk angsuran maupun dalam bentuk lump sum (sekaligus). Sehingga pembiayaan murabahah dengan jangka waktu panjang dapat menimbulkan risiko tidak bersaingnya bagi hasil kepada dana pihak ketiga. (Karim 2007)

Diantara kemungkinan risiko yang timbul dalam pembiayaan murabahah adalah Default atau kelalaian nasabah, fluktuasi harga komparatif, penolakan nasabah, dan dijual. (Antonio 2001).

Murabahah merupakan salah satu produk pembiayaan yang berbasis Natural Certainty Contracts (NCC), yang mana keputusan pembiayaan yang diambil sudah memperhitungkan risiko yang ada. Penilaian risiko ini mencakup dua aspek, yaitu Default Risk (risiko kebangkrutan), dan Recovery Risk (risiko jaminan). (Karim 2007)

\section{Risiko Pembiayaan Mudharabah}

Risiko yang terdapat dalam
mudharabah, terutama pada
penerapannya dalam pembiayaan, relatif
tinggi. Di antaranya adalah Side streaming
(nasabah menggunakan dana itu bukan
seperti yang disebut dalam kontrak), lalai
dan kesalahan yang disengaja, dan
penyembunyian keuntungan oleh
nasabah bila nasabahnya tidak jujur.
(Antonio 2001)


Mudharabah merupakan salah satu produk pembiayaan yang berbasis Natural Uncertainty Contracts yang mana tidak memberikan kepastian pendapatan, baik dari segi jumlah maupun waktunya. Pada jenis pembiayaan ini, penilaian risikonya mencakup 3 (tiga) aspek, yaitu Business Risk, Shrinking Risk, dan Character Risk. (Karim 2007)

\section{Manajemen Risiko}

Pelaksanaan

fungsi-fungsi

manajemen dalam mengatasi risiko secara umum dikenal dengan istilah manajemen risiko. Kegiatan manajemen risiko meliputi merencanakan, mengorganisir, menyusun, memimpin/mengkoordinir dan mengawasi (termasuk mengevaluasi) program penanggulangan risiko. (Djojosoedarso 1999)

Pada dasarnya, manajemen risiko dilakukan melalui tahapan-tahapan sebagai berikut (Hanafi 2009).

1. Identifikasi risiko, yaitu mengidentifikasi risiko-risiko apa saja yang dihadapi oleh suatu organisasi. Ada beberapa teknik untuk mengidentifikasi risiko, misal dengan menelusuri sumber risiko sampai terjadinya peristiwa yang tidak diinginkan.

2. Evaluasi dan pengukuran risiko. untuk memahami karakteristik risiko agar lebih mudah dikendalikan, maka suatu risiko harus dievaluasi. Evaluasi yang lebih sistematis dilakukan untuk mengukur risiko tersebut.

3. Pengelolaan risiko. Risiko bisa dikelola dengan berbagai cara, seperti penghindaran, ditahan (retention), diversivikasi, atau ditransfer ke pihak lainnya.

\section{Desain Penelitian}

Desain penelitian adalah penelitian kualitatif. Metode kualitatif digunakan untuk mendapatkan data yang mendalam dan mengandung makna yang merupakan data yang sebenarnya serta pasti yakni suatu nilai di balik data yang tampak.
Sehingga data kualitatif tidak menekankan pada generalisasi, namun lebih menekankan pada makna. (Sugiono 2009)

\section{Lokasi Penelitian}

Lokasi penelitian ini adalah BTM Surya Umbulharjo Yogyakarta yang berada di Jl. Glagahsari No. 136 Umbulharjo Yogyakarta, dan di Koperasi Jasa Keuangan Syariah (KSPPS) Baitul Maal wa Tamwil (BMT) Usaha Artha Sejahtera (UAS) yang terletak di Jl. Raya Lasem Km. 2 No. 27 Pamotan, Rembang, Jawa Tengah.

\section{Objek Penelitian}

Objek dalam penelitian ini adalah Manajemen Risiko Pembiayaan Murabahah di BTM Surya Umbulharjo Yogyakarta, dan Manajemen Risiko Pembiayaan Mudharabah pada KJSK BMT Usaha Artha Sejahtera (UAS) Pamotan Rembang Jawa Tengah.

\section{Populasi dan Sampel}

Populasi dalam penelitian kualitatif ini oleh Spradley dinamakan "social situation" atau situasi sosial yang terdiri atas tiga elemen yaitu: tempat (place), pelaku (actors), dan aktivitas (activity) yang berinteraksi secara sinergi (Sugiono 2009). Berdasarkan tiga elemen tersebut, penelitian ini bertempat di BTM Surya Umbulharjo Yogyakarta dan KSPPS BMT UAS Pamotan Rembang Jawa Tengah. Pelakunya adalah pegawai BMT yang memiliki wewenang dalam memanajemen risiko di BTM Surya Umbulharjo dan BMT UAS.

Penentuan sampel dalam penelitian kualitatif dilakukan saat peneliti mulai memasuki lapangan dan selama penelitian berlangsung (Sugiono 2009). Pemilihan sampel dalam penelitian kualitatif bertujuan untuk mendapatkan informasi yang maksimum. Adapun sampel dalam penelitian ini adalah Kepala dan Staff Bagian Pembiayaan BTM Surya Umbulharjo, Direktur dan Kepala Bagian Umum BMT UAS Pamotan, dan Manajer 
BMT UAS Cabang Bangilan, serta anggota BMT UAS.

\section{Instrumen Penelitian}

Data dalam penelitian ini dikumpulkan melalui wawancara dan dokumentasi. Model wawancara yang digunakan adalah wawancara semistruktur. Tujuan dari wawancara jenis ini adalah untuk menemukan permasalahan secara lebih terbuka, di mana pihak yang diajak wawancara dimintai pendapat, dan ide-idenya (Sugiono 2009). Adapun jenis dokumen yang digunakan dalam penelitian ini adalah dokumen pribadi, dan dokumen resmi. Dalam penelitian ini dokumen yang diteliti adalah arsip-arsip yang ada pada BTM Surya Umbulharjo dan BMT UAS.

\section{Analisis Data}

Analisis data yang digunakan dalam penelitian ini adalah deskriptif komparatif. Teknik analisis data deskriptif komparatif dimaksudkan untuk mengukur dan membandingkan dengan cermat fenomena sosial tertentu, dalam hal ini adalah penerapan manajemen risiko pembiayaan murabahah dan mudharabah di lembaga keuangan mikro syariah.

\section{HASIL DAN PEMBAHASAN}

\section{BTM Surya Umbulharjo}

BTM Surya Umbulharjo di dirikan pada tanggal 1 April 2012 M/09 Jumadil Ula $1433 \mathrm{H}$. Dan langsung bisa beroperasi pada tanggal 2 April 2012 M/10 Jumadil Ula 1433 H. Perkembangan anggota dari tahun berdiri hingga tahun 2015 mengalami peningkatan sebanyak 415 orang dari 323 di tahun 2014. Hal ini menunjukan tingkat kepercayaan yang sangat besar dari masyarakat terutama dari anggota persyarikatan untuk bergabung menjadi anggota dan memanfaatkan jasa pelayanaan BTM Surya Umbulharjo. Dari total anggota tersebut tercatat sebanyak 343 anggota memanfaatkan pembiayaan, baik pembiayaan Produktif (pengembangan usaha) maupun pembiayaan Konsumtif (BTM Surya UH, 2012).

Visi BTM Surya Umbulharjo adalah Terwujudnya lembaga jasa keuangan syariah yang islami, profesional, sebagai sumber, penggunaan dan pengelola utama dana AUM, Perserikatan, Anggota dan Masyarakat di wilayah kerjanya, serta memberikan pelayanan seluruh kebutuhannya. Adapun produk pembiayaan yang disediakan BTM Surya Umbulharjo adalah produk-produk dengan prinsip jual beli (murabahah), pembiayaan syirkah (kerjasama), prinsip ijarah/sewa, talangan/sebrakan (alqardh), dan pembiayaan qardul hasan.

\section{BMT Usaha Artha Sejahtera (UAS)}

BMT UAS berdiri sejak 19 Oktober 1998 dengan jumlah angota pendiri sebanyak 26 orang dengan simpanan pokok sebesar Rp. 250.000,- yang dapat diangsur sebanyak 12 kali, dan pada saat itu terkumpul saham pendiri sebesar Rp. 2.300.000,-. Pada awal operasinya, BMT UAS Pamotan mengontrak sebuah ruangan rumah dari salah satu pendiri, dengan jumlah pengelola sebanyak 5 orang. Sampai saat ini KSPPS BMT UAS Pamotan telah memiliki satu gedung pusat dan 12 kantor cabang. Jumlah pengelola saat ini sebanyak 130 pengelola serta 3 tenaga keamanan dan 3 tenaga kebersihan. Peningkatan ini juga diikuti dengan peningkatan aset dari tahun ke tahun yang hingga akhir tahun 2015 telah mencapai 109 miliar rupiah. (BMT UAS 2016)

Visi BMT UAS adalah meningkatkan kualitas ibadah anggota sehingga mampu berperan sebagai khalifah Allah. Jenis pembiayaan yang dibiayai yakni pada sektor pertanian, peternakan, perkebunan, perikanan, home industry, perdagangan, jasa, pertambangan. Adapun produk pembiayaan yang disediakan BMT Usaha Artha Sejahtera adalah Mudharabah (Bagi Hasil), Musyarakah (Bagi Hasil Bersyarikah), 
Murabahah (Pengadaan Barang Jatuh Tempo), Bai Bi Tsaman Ajil /BBA (Pengadaan Barang Cicilan), dan Qardhul Hasan. (BMT UAS 2016)

\section{Penerapan Manajemen Risiko Pembiayaan Murabahah di Lembaga Keuangan Mikro Syariah}

Langkah pertama yang dilakukan oleh BTM Surya Umbulharjo dalam manajemen risiko pembiayaan murabahah adalah identifikasi risiko. Identifikasi dilakukan untuk mengetahui risiko yang timbul dalam pembiayaan murabahah yang dikeluarkan oleh BTM Surya Umbulharjo kepada nasabah. Setidaknya terdapat empat risiko potensial yang ada di BTM Surya Umbulharjo, yaitu risiko pembiayaan, risiko pasar, risiko operasional dan risiko hukum. (BTM Surya UH)

Tahap kedua dalam manajemen risiko pembiayaan murabahah di BTM Surya Umbulharjo adalah evaluasi dan pengukuran risiko. Evaluasi merupakan tindakan yang dilakukan untuk mengontrol atau mengawasi sejauh mana penanganan risiko yang telah dilakukan agar tidak timbul risiko kembali. Evaluasi dilakukan langsung oleh manajer. Manajer akan memantau kerja karyawan yang ditugaskan untuk melakukan penanganan risiko pembiayaan murabahah, agar bisa terselesaikan dengan baik dan tidak terjadi risiko kembali. Selain dievaluasi, risiko juga diukur. Pengukuran risiko dibutuhkan sebagai dasar tolak ukur untuk memahami signifikansi dari akibat kerugian yang akan ditimbulkan oleh suatu risiko. Pelaksanaan pengukuran risiko di BTM Surya Umbulharjo disertai dengan evaluasi secara berkala terhadap kesesuaian asumsi, sumber data dan prosedur yang digunakan untuk mengukur risiko, seperti minimal adanya evaluasi pengukuran sewaktu-waktu, perbulan, triwulan.

Selanjutnya, apabila ada perubahan kegiatan usaha BTM, baik itu produk, transaksi, dan faktor risiko yang bersifat material yang dapat mempengaruhi kondisi keuangan BTM dan kegiatan usaha BTM, maka BTM Surya Umbulharjo akan melakukan penyempurnaan sistem pengukuran.

Tahap terakhir dari manajemen risiko di BTM Surya Umbulharjo adalah pengelolaan risiko yang timbul akibat pembiayaan murabahah. Pengelolaan risiko ini dilakukan dengan beberapa cara, yaitu pendampingan, pemberian modal kembali, perpanjangan jangka waktu pengembalian, pengembalian pokok saja, pemberian surat peringatan, sita jaminan, pencarian nasabah, dan hapus buku atau hapus tagih.

Penerapan Manajemen Risiko Pembiayaan Mudharabah di Lembaga Keuangan Mikro Syariah

Sama seperti pembiayaan murabahah, pembiayaan mudharabah juga memiliki risiko. Risiko yang terdapat dalam pembiayaan Mudharabah relatif tinggi, terutama pada penerapannya dalam pembiayaan (Antonio 2001). Identifikasi risiko digunakan untuk mengetahui risiko-risiko apa saja yang ada dalam penerapan pembiayaan mudharabah.

Proses identifikasi risiko di BMT UAS dilakukan melalui dua tahap yaitu pada saat awal permohonan pembiayaan mudharabah, dan pada saat melakukan survei sebelum realisasi pembiayaan mudharabah. Pada saat anggota baru mengajukan pembiayaan Mudharabah, BMT UAS mensyaratkan agar membawa kartu identitas dan juga jaminan. Selanjutnya pihak BMT UAS melakukan pengecekan kesesuaian antara identitas calon anggota dengan nama yang tercantum di jaminan tersebut. Hal ini dilakukan agar BMT dapat mengetahui bagaimana karakter nasabah, karena apabila dari awal sudah tidak jujur maka hal tersebut mengindikasikan bahwa karakter calon anggota tersebut kurang baik dan berpotensi adanya pembiayaan macet. (Mulyo 2017) 
"karakter ini sepenuhnya karena ini menyangkut pengelolaan dana sepenuhnya. Jadi itu yang kami tekankan bahwa asas prudensial yang paling tinggi ya emang disitu." (Sahuri 2017)

Setelah melewati proses administrasi, selanjutnya BMT UAS melakukan survei ke calon anggota tersebut. Adapun mekanisme survei dilakukan langsung dan tidak langsung. Survei langsung yakni pihak BMT mendatangi langsung calon anggota, dengan melakukan analisis usahanya yang terdiri dari beberapa aspek di antaranya adalah aspek manajemen, aspek jaminan, dan aspek usaha. (BMT UAS 2017)

Selain itu juga melihat di bidang usaha apa anggota tersebut mengajukan pembiayaan, karena pada dasarnya setiap bidang usaha memiliki karakteristik yang berbeda sehingga risikonya pun akan berbeda. Adapun risiko-risiko dalam pembiayaan Mudharabah yang dihadapi oleh BMT UAS Pamotan adalah sebagai berikut. (Sahuri 2017)

1. Risiko akad, risiko ini terjadi karena kurangnya edukasi kepada masyarakat mengenai akad Mudharabah, sehingga masyarakat menganggapnya masih seperti simpan pinjam pada umumnya.

2. Risiko yang terjadi dari segi pelaksanaannya yang mana ketika dana cair namun pengawasannya tidak ketat maka apabila anggota tidak amanah akan menyebabkan kerugian.

3. Risiko internal, yakni apabila pengelola kurang jeli dalam menganalisis nasabah maka akan penyebabkan kerugian besar pada lembaga, mengingat skim pembiayaan ini sangat besar risikonya.

4. Risiko yang ditimbulkan karena kondisi alam yakni pada pertanian dan perkebunan. Misalnya pada tanaman tebu, pada saat curah hujan tinggi maka tebu tidak bisa ditebang dan harganya turun.

Setelah risiko-risiko pembiayaan mudharabah teridentifikasi, tahap selanjutnya adalah evaluasi dan pengukuran risiko. Untuk mengukur tingkat pembiayaan, BMT UAS menggunakan software integrated micro banking system (IBS). Pengunaan IBS mempermudah BMT untuk mendapatkan informasi terkait anggota pembiayaan yang mengalami keterlambatan pembayaaran. Hal ini yang menjadi metode BMT dalam mengukur tingkat pembiayaan macet yang kemudian dibagi menjadi 4 jenis yaitu lancar, kurang lancar, diragukan, dan macet.

Dengan menggunakan software tersebut, BMT UAS dapat memantau pembayaran anggota, karena dengan menggunakan ini, pihak BMT sudah dapat mengukur tingkat pembiayaan macet satu bulan sebelumnya. Sehingga dengan mengetahui lebih awal potensi adanya risiko, pihak BMT dapat menanganinya sejak dini agar risiko dapat diminimalisir. (Sahuri 2017)

Adapun proses evaluasi atau pemantauan risiko yang dilakukan oleh BMT UAS guna untuk mengatisipasi risiko yang mungkin terjadi adalah pemantauan risiko melalui data dalam sistem pembukuan melalui software integraed micro banking system (IBS) dan survei kepada anggota.

Tahap terakhir dari manajemen risiko pembiayaan mudharabah adalah pengelolaan risiko. Untuk mengelola risiko pembiayaan Mudharabah yang sudah terjadi, BMT UAS menerapkan beberapa cara sebagai berikut.

1. Jika risiko tersebut disebabkan oleh kurangnya edukasi anggota tentang akad pembiayaan Mudharabah, maka BMT UAS akan memberikan penjelasan tentang bagaimana pembiayaan Mudharabah (BMT UAS 2017). Sehingga dengan adanya 
penjelasan di awal, diharapkan anggota dapat memahami apa itu pembiayaan Mudharabah serta ketentuan-ketentuannya yang telah tercantum pada akad pembiayaan Mudharabah. Hal ini sesuai dengan misi BMT UAS yakni meningkatkan manajemen pendampingan secara berkelanjutan bagi anggota agar lebih profesional dan islami. (BMT UAS 2016)

2. Jika disebabkan oleh musibah/bencana alam, bukan karena kelalaian, maka BMT memberikan toleransi waktu untuk yakni bisa diperpanjang, bisa juga toletansi waktu untuk menyelesaikannya (Sahuri 2017). Pemberian kelonggaran waktu pengembalian tersebut sesuai dengan QS Al Baqarah ayat 280 yang artinya: "Dan jika (orang yang berhutang itu) dalam kesukaran, maka berilah tangguh sampai dia berkelapangan. dan menyedekahkan (sebagian atau semua utang) itu, lebih baik bagimu, jika kamu mengetahui".

Hal ini dilakukan agar angggota bisa melakukan usaha baru dan bisa mengembalikan pinjamannya. Hal ini sesuai dengan tujuan didirikannya BMT UAS yakni untuk memajukan kesejahteraan anggota pada khususnya dan masyarakat pada umumnya.

3. Jika telah dilakukan penagihan namun tetap tidak membayar, maka akan dilakukan penyitaan jaminan. Namun sebelum dilakukan penyitaan, BMT UAS terlebih dahulu melakukan penagihan terus menerus, akan tetapi apabila memang benar-benar macet maka diperbolehkkan membayar pokok saja (Mulyo 2017). Namun jika solusi itu sudah tidak bisa, maka hal terakhir adalah dilakukan pelelangan jaminan. (BMT UAS 2017)
Analisis Komparatif Manajemen Risiko Pembiayaan Murabahah dan Mudharabah di Lembaga Keuangan Mikro Syariah

Pembiayaan murabahah yang berbasis margin keuntungan dan pembiayaan mudharabah yang berbasis bagi hasil memiliki kelemahan dan keunggulan tersediri. Kelamahan dan keunggulan yang ada ini menyebabkan kedua skim pembiayaan memiliki risiko yang berbeda, serta membutuhkan penerapan atau strategi manajemen risiko yang berbeda pula.

Penerapan manajemen risiko pembiayaan murabahah di BTM Surya Umbulharjo dan pembiayaan mudaharabah BMT Usaha Artha Sejahtera (UAS) dimulai dari proses identifikasi risiko, evaluasi dan pengukuran risiko, dan terakhir pengelolaan risiko.

Proses identifikasi risiko pembiayaan murabahah di BTM Surya Umbulharjo dilakukan sebagai langkah pertama dalam manajemen risiko pembiayaan murabahah. Risiko-risiko yang diidentifikasi oleh BTM Surya Umbulharjo terkait dengan pembiayaan murabahah adalah Risiko Pembiayaan, Risiko Pasar, Risiko Operasional, dan Risiko Hukum.

Sedangkan proses identifikasi risiko pembiayaan mudharabah di BMT UAS dilakukan pada saat awal permohonan pembiayaan mudaharabah oleh calon anggota, dan saat melakukan survei kepada calon anggota sebelum realisasi pembiayaan Mudharabah. Pada saat anggota baru mengajukan pembiayaan Mudharabah, BMT UAS mensyaratkan agar membawa kartu identitas dan jaminan. Selanjutnya pihak BMT UAS melakukan pengecekan kesesuaian antara identitas calon anggota dengan nama yang tercantum di jaminan tersebut. (Mulyo 2017)

Setelah melewati proses administrasi, selanjutnya BMT UAS melakukan survei ke calon anggota baik 
secara langsung maupun tidak langsung. Survei langsung dilakukan untuk menganalisis beberapa aspek terkait kegiatan usaha calon anggota (BMT UAS 2017).

\section{Proses identifikasi risiko} pembiayaan mudharabah lebih detail dibandingkan proses identifikasi risiko pembiayaan murabahah. Hal ini dikarenakan risiko yang terdapat dalam pembiayaan Mudharabah relatif tinggi, terutama pada penerapannya dalam pembiayaan (Antonio 2001).

Menurut Rivai dan Veithzal (2010), identifikasi kebijakan pembiayaan harus secara jelas tentang tata cara dan prosedur dokumentasi dan adminisrtrasi pembiayaan yang minimal memuat jenis dokumen pembiayaan yang diperlukan seperti KTP dan KK, pengecekan keabsahan dokumen pembiayaan yakni kesesuaian nama dari barang yang dijaminkan dengan identitas anggota yang mengajukan pembiayaan. selain itu, proses identifikasi harus memperhatikan kondisi keuangan mudharib, khususnya kemampuan membayar tepat waktu, serta jaminan atau agunan yang diberikan. Untuk risiko mudharib, penilaian harus mencakup analisis terhadap lingkungan mudharib. (Rivai dan Veithzal 2010)

Pada tahap kedua, BTM Surya Umbulharjo melakukan evaluasi dan pengukuran risiko pembiayaan murabahah. Evaluasi dilakukan untuk mengontrol atau mengawasi sejauh mana penanganan risiko yang telah dilakukan agar tidak timbul risiko kembali. Selain evaluasi, BTM Surya Umbulharjo juga melakukan pengukuran risiko sebagai dasar tolak ukur untuk memahami signifikansi dari akibat kerugian yang akan ditimbulkan oleh suatu risiko. Pelaksanaan evaluasi dan pengukuran risiko ini dilakukan secara berkala terhadap kesesuaian asumsi, sumber data dan prosedur yang digunakan.

Sama hal nya dengan BTM Surya Umbulharjo, pada tahap kedua BMT UAS juga melakukan pengukuran risiko dan evaluasi terhadap pembiayaan mudharabah. Pengukuran risiko pembiayaan mudharabah dilakukan dengan menggunakan sistem manajemen informasi yang terintegrasi melalui software integraed micro banking system (IBS). Evaluasi atau pemantauan risiko pembiayaan mudharabah di BMT UAS dilakukan melalui data dalam sistem pembukuan melalui IBS, dan survei kepada anggota pembiayaan mudharabah.

Menurut Rustam (2013), lembaga harus memiliki sistem dan prosedur tertulis untuk melakukan pengukuran risiko yang memungkinkan untuk distribusi informasi hasil pengukuran risiko secara lengkap untuk tujuan pemantauan oleh satuan kerja terkait. (Rustam 2013)

Adapun terkait dengan pemantauan risiko menurut Rivai dan Veithzal (2010), lembaga harus mengembangkan dan menerapkan sistem informasi dan prosedur yang komprehensif untuk memantau kondisi anggota. sistem pemantauan risiko pembiayaan sekurangkurangnya memuat ukuran-ukuran dalam rangka memastikan kondisi keuangan terkahir dari mudharib, memantau kepatuhan terhadap persyaratan dalam perjanjian pembiayaan atau kontrak transaksi risiko pembiayaan, menilai kecukupan agunan dibandingkan dengan kewajiban mudharib, serta mengidentifikasi ketidaktepatan pembayaran dan mengklasifikasi pembiayaan bermasalah secara tepat waktu. (Rivai dan Veithzal 2010).

Tahap terakhir dari manajemen risiko adalah pengelolaan risiko. Pengelolaan risiko pembiayaan murabahah di BTM Surya Umbulharjo dilakukan dengan beberapa cara, seperti pendampingan, pemberian modal kembali, perpanjangan jangka waktu pengembalian, pengembalian pokok, pemberian peringatan, sita jaminan, pencarian nasabah (bagi nasabah yang 
melarikan diri), dan hapus buku atau hapus tagih.

Sedangkan pengelolaan risiko pembiayaan mudharabah yang sudah terjadi di BMT UAS dilakukan dengan cara memberikan penjelasan tentang bagaimana pembiayaan Mudharabah jika risiko tersebut disebabkan oleh kurangnya edukasi anggota tentang akad pembiayaan Mudharabah, pemberian kelonggaran waktu pengembalian jika disebabkan oleh musibah/bencana alam, bukan karena kelalaian, membayar pokok saja, dan penyitaan jaminan jika telah diberikan kelonggaran dan dilakukan penagihan namun tetap tidak membayar.

Bambang Rianto Rustam (2013) berpendapat bahwa salah satu kebijakan yang bisa dilakukan oleh lembaga yakni penetapan tingkat risiko dan toleransi risiko (Rustam 2013). Salah satu bentuk toleransi risiko adalah pemberian kelonggaran waktu pengembalian. Pemberian kelonggaran waktu pengembalian tersebut sesuai dengan QS Al Baqarah ayat 280:

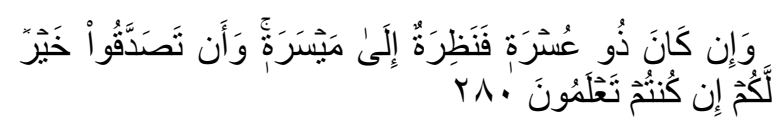

Artinya: Dan jika (orang yang berhutang itu) dalam kesukaran, Maka berilah tangguh sampai dia berkelapangan. dan menyedekahkan (sebagian atau semua utang) itu, lebih baik bagimu, jika kamu Mengetahui". (QS. Al Baqarah: 280)

Risiko-risiko yang ada pada skim pembiayaan murabahah dan skim pembiayaan mudharabah berkaitan erat dengan kelemahan dan keunggulan yang ada pada kedua skim pembiayaan tersebut.

Pembiayaan dengan akad murabahah merupakan pembiayaan yang masuk ke dalam golongan Natural Certainty Contracts (NCC). Penilaian risiko pembiayaan berbasis NCC mencakup dua hal, yaitu risiko kebangkrutan (default risk) dan risiko jaminan (recovery risk)
(Karim 2007). Keunggulan pembiayaan murabahah adalah mudah diaplikasikan, dan risikonya relatif kecil dibanding pembiayaan mudharabah. Sedangkan kelemahan pembiayaan murabahah adalah terletak pada pembiayaan murabahah dengan jangka waktu panjang, yaitu adanya kemungkinan pembiayaan macet.

Menurut Asiyah (2015), manfaat dari pembiayaan dengan prinsip murabahah adalah adanya keuntungan yang muncul dari selisih harga beli dan harga jual kepada nasabah, serta bentuk pembiayaannya sederhana sehingga memudahkan administrasi di bank syariah. (Asiyah 2015)

Adapun kemungkinan risiko yang timbul dalam pembiayaan murabahah adalah sebagai berikut. (Antonio 2001)

1. Default atau kelalaian, nasabah sengaja tidak membayar angsuran.

2. Fluktuasi harga komparatif. Ini terjadi bila harga suatu barang dipasar naik setelah bank membelikannya untuk nasabah. Bank tidak bisa mengubah harga jual beli tersebut.

3. Penolakan nasabah; barang yang dikirim bisa saja ditolak oleh nasabah karena berbagai sebab antara lain rusak dalam perjalanan.

4. Dijual; karena pembiayaan murabahah bersifat jual beli dengan utang, maka ketika kontrak ditanda tangani, barang itu menjadi.

Sedangkan pembiayaan dengan akad mudharabah merupakan pembiayaan yang berbasis Natural Uncertainty Contracts (NUC). Penilaian risiko pembiayaan mudharabah mencakup tiga hal, yaitu risiko bisnis yang dibiayai (business risk), risiko berkurangnya nilai pembiayaan mudharabah (shrinking risk), dan risiko karakter buruk mudharib (character risk) (Karim 2007).

Risiko yang terdapat dalam alMudharabah, terutama pada penerapannya dalam pembiayaan, relatif 
tinggi (Antonio 2001). Hal ini disebabkan oleh beberapa permasalahan seperti Asymmetric information dan Moral hazard (Karim 2007). Selain kedua permasalahan tersebut, penyebab tingginya risiko dalam pembiayaan mudharabah adalah kerena mudharabah merupakan skim pembiayaan yang berbentuk investasi, yang penghasilan atau bagi hasilnya tidak tetap. Sebagai suatu investasi, mudharabah dipengaruhi oleh banyak faktor, baik faktor internal maupun faktor eksternal. Kelemahan dari pembiayaan mudharabah adalah adanya kemungkinan pembiayaan macet, dan tingkat bagi hasil rendah. Adapun keunggulan pembiayaan mudharabah adalah pembiayaan dengan skim mudharabah menjanjikan pendapatan atau bagi hasil yang lebih besar dibandingkan skim pembiayaan murabahah jika investasi yang dikelola berhasil.

Adapun risiko yang mungkin timbul dari pelaksanaan pembiayaan mudharabah adalah side streaming (nasabah menggunakan dana itu bukan seperti yang disebut dalam kontrak), lalai dan kesalahan yang disengaja, dan penyembunyian keuntungan oleh nasabah bila nasabahnya tidak jujur (Antonio 2001).

\section{KESIMPULAN}

Perbandingan manajemen risiko antara produk pembiayaan murabahah dan mudharabah di Lembaga Keuangan Mikro Syariah dapat dilihat dari proses identifikasi risiko, pengukuran dan evaluasi risiko, dan pengelolaan risiko.

Proses identifikasi risiko pembiayaan murabahah di BTM Surya Umbulharjo dilakukan sebagai langkah pertama dalam manajemen risiko pembiayaan murabahah. Risiko-risiko yang diidentifikasi oleh BTM Surya Umbulharjo terkait dengan pembiayaan murabahah adalah Risiko Pembiayaan, Risiko Pasar, Risiko Operasional, dan Risiko Hukum. Sedangkan proses identifikasi risiko pembiayaan mudharabah di BMT UAS dilakukan pada saat awal permohonan pembiayaan mudaharabah oleh calon anggota, dan saat melakukan survei kepada calon anggota sebelum realisasi pembiayaan Mudharabah.

Selanjutnya proses pengukuran dan evaluasi risiko. Proses pengukuran risiko pembiayaan murabahah di BTM Surya Umbulharjo dilakukan sebagai dasar tolak ukur untuk memahami signifikansi dari akibat kerugian yang akan ditimbulkan oleh suatu risiko. Adapun proses evaluasi risiko pembiayaan murabahah di BTM Surya Umbulharjo dilakukan untuk mengontrol atau mengawasi sejauh mana penanganan risiko yang telah dilakukan agar tidak timbul risiko kembali. Pelaksanaan evaluasi dan pengukuran risiko ini dilakukan secara berkala terhadap kesesuaian asumsi, sumber data dan prosedur yang digunakan. Sedangkan proses pengukuran risiko pembiayaan mudharabah di BMT UAS dilakukan dengan menggunakan sistem manajemen informasi yang terintegrasi melalui software integraed micro banking system (IBS). Adapun proses evaluasi atau pemantauan risiko pembiayaan mudharabah di BMT UAS dilakukan melalui data dalam sistem pembukuan melalui IBS, dan survei kepada anggota pembiayaan mudharabah.

Terakhir adalah pengelolaan risiko. Di BTM Surya Umbulharjo, pengelolaan risiko pembiayaan murabahah dilakukan dengan beberapa cara seperti pendampingan, pemberian modal kembali, perpanjangan jangka waktu pengembalian, pengembalian pokok, pemberian peringatan, sita jaminan, pencarian nasabah (bagi nasabah yang melarikan diri), dan hapus buku atau hapus tagih. Sedangkan di BMT UAS, pengelolaan risiko pembiayaan 
mudharabah yang sudah terjadi dilakukan dengan cara memberikan penjelasan tentang bagaimana pembiayaan Mudharabah, pemberian kelonggaran waktu pengembalian, membayar pokok saja, dan penyitaan jaminan.

\section{DAFTAR PUSTAKA}

Antonio, Muhammad Syafi'i. 2001. Bank Syariah Dari Teori ke Praktik. Jakarta: Gema Insani.

Asiyah, Binti Nur. 2015. Manajemen Pembiayaan Bank Syariah. Yogyakarta: Kalimedia.

BMT UAS. 2017. Kesepakatan Akad Pembiayaan Mudharabah. Rembang: BMT UAS.

-. 2016. Profil Perusahaan KSPPS BMT UAS Pamotan. Rembang: BMT UAS.

Djojosoedarso, Soeisno. 1999. Prinsipprinsip Manajemen Risiko dan Asuransi. Jakarta: Salemba Empat.

DSN MUI. 2000. "Fatwa DSN MUI No: 7/DSN-MUI/IV/2000."

Hanafi, Mamduh M. 2009. Manajemen Risiko. Yogyakarta: UPP STIM YKPN.

Iqbal, Zamir, dan Abbas Mirakhor. 2008. Pengantar Keuangan Islam: Teori dan Praktik. Jakarta: Kencana.
Karim, Adiwarman A. 2007. Bank Islam: Analisis Fiqih Dan Keuangan. Jakarta: Raja Grafindo Persada.

Mulyo, Wiji. 2017. Implementasi Manajemen Risiko (16 Mei).

OJK. 2016. Statistik Perbankan Syariah. Jakarta: Otoritas Jasa Keuangan.

Rivai, Veithzal, dan Andria Permata Veithzal. 2010. Islamic Financial Management. Jakarta Utara: Rajawali Pers.

Rustam, Bambang Rianto. 2013. MANAJEMEN RISIKO Perbankan Syariah di Indoneisa. Jakarta: Salemba Empat.

Sahuri. 2017. Kebijakan dan Strategi (19 Mei).

Sudarsono, Heri. 2008. Bank dan Lembaga Keuangan Sariah Deskriptif dan Illustrasi. 3. Yogyakarta: Ekonisia.

Sugiono. 2009. Memahami Penelitian Kualitatif. Bandung: Alfabeta.

Widodo, Sugeng. 2014. Moda Pembiayaan Lembaga Keuangan. Yogyakarta: Kaukaba.

Wiroso. 2005. Jual Beli Murabahah. Yogyakarta: UII Press.

Yusuf, Sri Dewi. 2013. "Peran Strategis Baitul Maal Wa Tamwil (BMT) Dalam Meningkatkan Ekonomi Rakyat." ipi266176 